\title{
Consumer Attitude to New Products in Banks N Nigeria In Post-Consolidation Period
}

\author{
Eboreime Ohimai Friday (Ph.D), Gbandi Eleazar Chibuzor (Ph.D) \\ Department of Business Administration Benson Idahosa University, Benin City, Nigeria. \\ Department of Business Administration Benson Idahosa University, Benin City, Nigeria.
}

\begin{abstract}
In 2004, Nigeria undertook a reform in the banking cub-sector for consolidation and merger of banks as some developing countries have done in the past. In the process, enhanced profitability and market power motive led the banks to float large staple variety new and sophisticated products, especially electronic products mid services. The patronage of these new products initially experienced upsurge but later had a decline. The objective of' this study is to investigate and confirm the subsequent decline in patronage of some of the new products and the reasons for the negative attitude of consumers to the new products of banks at this period. After an opinion survey analysis, the major findings are that there were subsequent negative changes in the patronage of new product, especially electronic products after their introduction. This has been attributed to lack of perceived value by customers, excessive and multiple bank charges, the discrimination in granting credits and untoward activities of internet fraudsters. It is recommended that the bank management should ensure; that they research into how products introduced by bank will add value to customer's .satisfaction and an minimum costs, especially in this time of global economic recession. In addition, banks should adhere strictly to the apex banks regulations and 'arm "themselves properly to prevent fraudulent activities of internet fraudsters. The Apex bank should formulate policies that will restore confidence in the commercial banking system.
\end{abstract}

Keywords:- New product, Consumer behavior, Value creation, Post-consolidation.

\section{INTRODUCTION}

The marketing of services (including worldwide has grown considerably in recent years, especially in developed countries. In U.S., for instance, services account for 14 percent of U.S. gross domestic product and about $60 \%$ of persnal consumption expenditure in 1970 and 1996 accounted for 80 percent of the total employment (Kotler and Armstrong, 2004). Most developing Countries have embraced reforms in the banking sector. For instance, to increase and improve their services in Nigeria, the Central Bank of Nigeria (CBN) Banking Reform of 2004 on the consolidation and recapitalization of banks was mainly aimed at integrating banks to enhance efficiency bank productivity and consequently improve the equity base and post merger performance or the consolidation of banks and mergers of banks. This has led to the birth of "mega" banks with expansion in his production and marketing activities, resulting in enhanced profitability, economies of scale, large capital base, increased market power and diversification of risks (lkparnejo, et al, 2006). A notable feature of the post consolidation period of banks in Nigeria was that the enhanced profitability and services, which attracted large number of customers in some of the services while others, had little or no patronage.

"Inspite of the high cost of introducing new products, intensive adverts and variety of sales promotes, many new products of banks which initially experienced upsurge of demand are not showing any increase in patronage of some electronic products of many banks, such as Automated Teller Machine (ATM) is now decreasing because of the prevalent untoward activities in cheating customers. Other products, such as internet banking value card or master card, mortgage and new credit products are less patronized", (Ikpamejo, 2006). In addition, according to Anaro (2008), excessive charges discouraged customers. He gave the example of the transaction cost of ATM, which increased from 50\% in previous year to 100\% percent in September, 2008. He further stated that "most banks found it convenient to impose multiple charges, which were not provided for in CBN's Guide to Bank Charges." These poor negative attitudes of customers have been largely traced to excessive bank charges. He pointed out that in addition to poor planning, execution and control, oversophisticated and untested products, poor market targeting and non-consideration of the environmental and cultural attitudes of the customers have also been identified as causes of low patronage by him.

This study is therefore aimed at empirically investigating the marketability, patronage and reasons for the negative attitude of consumers if any to new products of banks in post-consideration era in Nigeria and makes corporate recommendations to bank managers in handling customers' negative attitude in patronizing new products. 


\section{THE CONCEPT OF NEW PRODUCT}

The first thing to know about the concept of new product is that new product rarely exists and there is no unanimity as to what constitutes a new product. This is because a truly new product is one that nothing like it has been made before. For a company, a new product is one that is new to the company, but not necessarily new to the market where the generic product may already exist (Nwokoye, 2004). In the real sense, this type of product is product innovation and not new product.

Dunne (1974), gave three categories of new products, namely products that are truly unique or innovative, products that can be considered replacement for existing ones but which arc significantly different from existing ones and products that are new to a particular company but not new to the industry or market, because it has something unique to offer. Dunne concluded that, "in his view, the key element in determining what a new product is, is consumer perception rather than the degree of technical change".

\section{MODELS OF CONSUMER BEHAVIOUR}

An indepth understanding of the various models and influences on consumer behaviour is important to marketers and the management of the company because they serve as guides and tools for evaluation of market opportunities, designing the market segmentation, targeting and positioning and finally designing marketing strategies for the new products. Many models exist in marketing literature for analysis of consumer behaviour. Here, we shall highlights the major ones. One of the models is Kotler's Behavioural Choice Model, which states that the in inputs (buyer's influences) are processed in the buyers "black box" (psyche) or mind that result in series of responses, which can be controlled by the marketer (Kotler, 1965). Sheith's Theory of Family Buying Decisions, shows that buying decisions are jointly made by the family, depending a number of factors, such as autonomy of the buying member of family, life cycle of the family, predisposition of the family member towards his buying motives and his evaluative beliefs (Sheith and Howard, 1966). On the other hand, another Howard Sheith model of brand choice behaviour of the buyer is based on input (stimuli) and output (behaviour) interaction. This model improved on Kotler's model as it explained what goes on between and input and output in making buying decisions. The Eagel et al models are shown in two decision-making models, namely a high involvement decision process and low involvement decision process, which may result in two possible outcomes of satisfaction or dissonance. The final decision of the two is the "direct outcome of beliefs directly by the evaluative criteria, and satisfaction which produce use and indirectly by lifestyle, normative compliance and information influence and remotely by culture and reference groups" (Agbonifoh, 1998).

In all these models, the implication is that the marketer is affected by several factors, namely, economic, social and cultural, political and physiological psychographic factors Therefore, these factors will help the marketer to influence buying decisions. 'hoc warning is that although, marketers usually try to understand and influence buying behaviour, they cannot control it" (Bamgboye, 2003).

\section{CREATING VALUE FOR CUSTOMERS}

Creating value or making customers to perceive products or services worthy can be called the "value chain," according to Porter (1985). This consists of several primary and secondary activities. The primary value chain activities include inbound logistics, which include raw materials, supply and production activities of initiatives of meeting customer expectation at the lowest possible cost. Smith (2004) concludes on this subject matter by stating the condition for the value creation, that 'if customers do not perceive that your products offer good value for money, none of your efforts are likely to matter. Therefore, the issue of creation or adding value which has been revived in the twenty first century is central to matters of product demand in the competitive market. Recently, Etzel et al. (2007), posited that 'customers access service quality by comparing their expectations to the perception of how the service is performed." therefore he advised firms to strive to maintain consistent service quality at or above the expectation level.

\section{CHALLENGES IN NEW PRODUCT DEVELOPMENT}

From the history of production, new products continue to fail inspite of sophisticated technology and the investigation of buyers motivations and behaviour (Bamgboye, 2003). Hopkins and Bailer (1971) listed five reasons why new products fail. These are inadequate market analysis, product deficiencies, lack of effective strength or reaction, poor timing of introduction and technical or production problems. On the other hand, Davidson (1977) identifies six reasons for marketing failures, which originate from managerial behaviour. These are unreal time pressure, inflexible objectives, fear, vested interests, arrogance and absorption in the introduction process.

In his opinion, Bamgboye (2003) simply emphasizes that failure to appreciate customer's want as the main reason for the failure of many products, though how o appreciate customer's want was not shown by him. 
However, Agbonifoh (1998) had already expatiated on appreciation of customers' want, that it involves not just exploratory survey on customers want but 'suggest need for more studies, using perhaps, more vigorous instruments." Fujikawa (2008) recently in Harvard Business Case Commentary, clarified these issues by pointing out that traditional research doesn't help marketers to form a coherent picture of customers' attitudes, instead, 'the company needs to dive into customers' conscious and unconscious minds from psychological and cognitive methods and this creates a bond which cannot he imitated by competitors." The problem here lies in digging into customer's unconscious minds. Therefore, the theoretical framework of this study will be anchored on the following propositions:

1. Ikpamejo (2006) posited that a notable feature of the post consolidation of banks in Nigeria was that the enhanced profitability and market power motivated the banks to float large staple of variety of new products (especially electronic products) and services, which attracted large number of customers in some services, while others had little or no patronage.

2. Ikpamejo (2008) observed that the patronage of some electronic products of many banks, such as Automated Teller Machine (ATM) is now decreasing because of the prevalent untoward activities of fraudsters in defrauding customers,

3. Ikpamejo (2008) also pointed out that other products such as internet banking, value card, mortgage and new credit card products are less patronized mainly because of bureaucracy and stringent, requirements of collateral security.

4. Anaro (2008) observed that excessive and multiple charges of banks discourage the patronage of new products, such as ATM, which were not provided for in Central Banks of Nigerians (CBN) Guidelines to Bank Charges.

5. Bamgboye (2003) emphasized that failure to appreciate customers' want and expectation (perceived value) is the main reason for less patronage and failure of many products.

6. The final decision of consumer behaviour theories of Kotler (1965), Sheith and Howard (1966) is the "direct outcome of beliefs directly by the evaluative criteria and satisfaction with product use and indirectly by lifestyle, normative compliance and informational influence and remotely by culture and reference groups." (Agbonifoh. 1998).

\section{ASSUMPTION}

For the purpose of this study, the assumption is that most customers of the banks are not fully aware of the value and operations of the new products of the banks.

\section{RESEARCH METHODOLOGY}

The survey research method was used for the collection of data for this study but was restricted to case studies of six selected banks in Benin City metropolis of Edo State of Nigeria. However, Benin City with many satellite towns of different ethnic groups gives room for studying both urban and rural consumers' attitude and behaviour in patronizing products of the banks. The sampling method employed in this study is judgmental sampling which though non-probability method allows the research to select sampling units from the research population based on the knowledge of the population. This gives a reasonable picture of the study of the attitude of some multi-ethnic groups in Edo State though they may not be representative of the entire Nigerian population.

The study used the structured questionnaire for bank customers, who are the focus of this study and personal interview for bank workers to avoid official embarrassment. A total of 350 questionnaires were administered and 296 completed ones constituting 87\%, were successfully retrieved. The Likert scale of measurement with a 5 point continuum with corresponding weight for possible answers, depending on the extent of the respondent intensity to agreement or disagreement to a given statement, was used. This is found suitable to measuring statements that reflect attitudes and feelings of consumers by respondents, who are customers of these selected banks.

Based on the above, the following hypotheses. Interlia, were tested to determine the relationship of the data collected on the patronage and attitude of customers to new products of banks in post-consolidation era in Nigeria.

(1) There is no significant relationship between the introduction of new products by banks and the reduction in their patronage.

(2) There is no significant relationship between the fraudulent activities of internet fraudsters and criminals on electronic products and the negative attitude of bank customer towards the patronage of the products.

(3) That there is no significant difference between the patronage of banks by customers and the discouragement of patronage of customers of electronic products due to the excessive and multiple charges of banks. 
(4) That there is no significant difference between the patronage of new products banks by customers and poor customers' perceived value of new products.

(5) That there is no significant difference between the patronage of new products of banks and the nonconsideration of beliefs and cultural factors of the people in the environment.

\section{DATA ANALYSIS}

As earlier stated, the testing of hypotheses was carried with the use of Chi-Square and the computed with Linkert' scale 5 - point continuum. The Chi-Square is used in testing the relationship between variables and invariably useful in accepting and rejecting hypothesis. The data collected were presented in tables while the results were tested for significance at the level of 0.05 , as shown below. The five hypotheses were been tested and analyzed as follows:

\section{HYPOTHESIS ONE:}

Table I Linkert Scale Scores For Respondents For Introduction Of New Products And

Patronage By Bank Customers

\begin{tabular}{|l|l|l|c|c|c|}
\hline & \multicolumn{1}{|c|}{$\begin{array}{c}\text { Observed } \\
\text { Frequency } \\
(\mathbf{0})\end{array}$} & $\begin{array}{c}\text { Expected } \\
\text { Frequency } \\
(\mathbf{0})\end{array}$ & $\begin{array}{c}\text { Residual } \\
(\mathbf{0}-\mathbf{E})\end{array}$ & $\mathbf{( 0 - E )}^{\mathbf{2}}$ & $\begin{array}{c}\text { Chi-Square } \\
\frac{(\mathbf{0}-\mathbf{E})^{\mathbf{2}}}{\mathbf{2}}\end{array}$ \\
\hline Strongly (SA) & $100(5)=500$ & 207.2 & 292.8 & 85731.8 & 413.8 \\
\hline Agree (A) & $70(4)=280$ & 207.2 & -72.8 & -5300.0 & 25.6 \\
\hline Agree & $30(3) 90$ & 207.2 & -117.2 & 13735.8 & -66.3 \\
\hline Indifferent (I) & $70(2)=140$ & 207.2 & -67.2 & -4516.0 & -21.8 \\
\hline Strongly Disagree (SD) & $26(1)=26$ & 207.2 & -181.2 & 32833.4 & -158.5 \\
\hline Total & & $\mathbf{1 0 3 6}$ & & & $\mathbf{1 4 1 . 6}$ \\
\hline
\end{tabular}

Significant at 0.05 levels

Hypothesis one states that there is no significant relationship between the reduction in the patronage of banks by customers and the introduction of new products. From the data presented in Table I, the analysis of results reveal that the calculated chi-square value of 141.6 was found to be higher than the critical table chisquare value of 0.71 at 4 degree of freedom and 0.05 level of significance. The null hypothesis was therefore rejected. The findings imply that there is significant relationship between the reduction in the patronage of banks by customers and the introduction of new products by banks.

\section{HYPOTHESIS TWO:}

TABLE 2 RELATIONSHH' BETWEEN THE FRAUDULENT ACTIVITIES OF INTERNET FRAUDSTERS AND-THE NEGATIVE ATTITIJDE OF BANK CUSTOMERS TOWARDS THE PATRONAGE OF THE PRODUCTS

\begin{tabular}{|l|l|l|c|c|c|}
\hline & $\begin{array}{c}\text { Observed } \\
\text { Frequency } \\
(\mathbf{0})\end{array}$ & $\begin{array}{c}\text { Expected } \\
\text { Frequency } \\
(\mathbf{0})\end{array}$ & $\begin{array}{c}\text { Residual } \\
(\mathbf{0}-\mathbf{E})\end{array}$ & $\mathbf{( 0 - E )}^{\mathbf{2}}$ & $\begin{array}{c}\text { Chi-Square }_{(\mathbf{0 - E})^{\mathbf{2}}} \\
\mathbf{2}\end{array}$ \\
\hline Strongly (SA) & $-80(5)=425$ & 166.4 & 258.6 & 668740 & 401.9 \\
\hline Agree (A) & $72(4)=148$ & 166.4 & -18.4 & 338.6 & -2.0 \\
\hline Agree & $20(3)$ & 166.4 & 106.4 & 11321.0 & -68.0 \\
\hline Indifferent (I) & $80(2) 160$ & 166.4 & -6.4 & 41.0 & -0.3 \\
\hline Strongly Disagree (SD) & $39(1)=39$ & 166.4 & -127.4 & 16230 & -97.5 \\
\hline Total & 832 & & & & $\mathbf{2 3 4 . 1}$ \\
\hline
\end{tabular}

Significant at 0.05 levels

Hypothesis two states that there is no significant relationship between the fraudulent activities of internet fraudsters and criminals on electronic products and the negative attitude of bank customers towards the patronage of the products. From Table 2, the analysis of results reveals that the calculated chi-square value of 234. 1 was found to be higher than the critical table chi-square value of 0.71 at 4 degree of freedom and 0.05 level of significance. The null hypothesis was therefore rejected.

The findings imply that there is significant relationship between the negative behaviour of customers on the patronage of electronic and the fraudulent activities pf internet fraudsters. 
HYPOTHESIS THREE:

TABLE 3 Relationship Between Excessive Bank Charges Decreased Patronage On Electronic Products

\begin{tabular}{|c|c|c|c|c|c|}
\hline 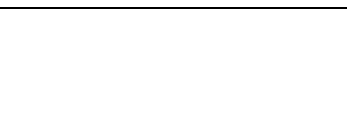 & $\begin{array}{c}\text { Observed } \\
\text { Frequency } \\
\text { (0) }\end{array}$ & $\begin{array}{c}\text { Expected } \\
\text { Frequency } \\
(0)\end{array}$ & $\begin{array}{c}\text { Residual } \\
\text { (0-E) }\end{array}$ & $(0-E)^{2}$ & $\begin{array}{l}\text { Chi-Square } \\
\frac{(0-E)^{2}}{2}\end{array}$ \\
\hline Strongly (SA) & $75(5)=735$ & 184.0 & 191.0 & 36.481 .0 & 198.3 \\
\hline Agree (A) & $74(4)=296$ & 184.0 & 112.0 & $12,544.0$ & 68.2 \\
\hline Agree & $13(3)=39$ & 184.0 & -145 & $21,025.0$ & -111.3 \\
\hline Indifferent (I) & $75(2) 150$ & 184.0 & -34 & -1156.0 & 6.3 \\
\hline Strongly Disagree (SD) & $60(1)=60$ & 184.0 & -124 & -15371.0 & 836 \\
\hline Total & Total & 920 & & & 62.3 \\
\hline
\end{tabular}

Significant at 0.05 levels Hypothesis three states that there is no significant relationship between the decreased patronage of electronic products by customers of bank and excessive and multiple bank changes by banks. The data presented in Table 3 also reveal that the calculated chi-square value of 62.3 was found to be higher than the critical table chi-square value of 0.71 . The null hypothesis was therefore rejected.

The findings imply that there is significant relationship between the decreasing patronage of electronic products by customers of banks and excessive and multiple bank charges of banks.

\section{HYPOTHESIS FOUR:} TABLE 4 RELATIONSHIP BETWEEN THE POOL PERCEIVED VALUE OF NEW PRODUCTS BY
BANK CUSTOMERS AND THE NEGATIVE ATTITUDE OF CUSTOMERS TOWARDS THE
PATRONAGE OF NEW PRODUCTS

\begin{tabular}{|c|c|c|c|c|c|}
\hline (2) & $\begin{array}{c}\text { Observed } \\
\text { Frequency } \\
(\text { (0) }\end{array}$ & $\begin{array}{l}\text { Expected } \\
\text { Frequency } \\
(0)\end{array}$ & $\begin{array}{c}\text { Residual } \\
(0-E)\end{array}$ & $(0-E)^{2}$ & $\begin{array}{c}\text { Chi-Square } \\
\frac{(0-\mathbf{E})^{2}}{2}\end{array}$ \\
\hline Strongly (SA) & $65(5)=325$ & 151.8 & 173.2 & $29,998.2$ & 197.6 \\
\hline Agree (A) & $62(4)=128$ & 151.8 & -23.8 & -566.4 & -3.7 \\
\hline Agree & $31(3)=93$ & 151.8 & -58.8 & -3457.4 & -22.6 \\
\hline Indifferent (I) & $75(2)=150$ & 151.8 & -1.8 & -12 & -1 \\
\hline Strongly Disagree (SD) & $63(\mathrm{I})=63$ & 151.8 & -88.8 & -177.6 & -12 \\
\hline Total & 759 & & & & 169.80 \\
\hline
\end{tabular}

Significant at 0.05 levels

Hypothesis four states that there is no significant relationship between the poor perceived value of new products by bank customers and the negative attitude of customers towards the patronage of new products. From the data presented in Table 4 , the analysis of results show that the calculated chi-square value of 169.8 was found to be higher than the critical table chi-square value of 0.71 . The null hypothesis was therefore rejected.

The findings imply that there is significant relationship between the poor perceived value of new products by bank customers and the negative attitude by customers towards the patronage of new products.

\section{HYPOTHESIS FIVE: TABLE 5 RELATIONSHIP OF NON-CONSIDERATION OF BELIEFS AND CULTURAL FACTORS OF THE ENVIRONMENT AND THE LOW PATRONACE OF NEW PROD UCTS}

\begin{tabular}{|l|l|l|l|l|l|}
\hline & \multicolumn{1}{|c|}{$\begin{array}{c}\text { Observed } \\
\text { Frequency } \\
(\mathbf{0})\end{array}$} & $\begin{array}{c}\text { Expected } \\
\text { Frequency } \\
(\mathbf{0})\end{array}$ & $\begin{array}{c}\text { Residual } \\
(\mathbf{0 - E})\end{array}$ & $\mathbf{( 0 - E )}^{\mathbf{2}}$ & $\begin{array}{c}\text { Chi-Square } \\
\frac{(\mathbf{0}-\mathbf{E})^{\mathbf{2}}}{\mathbf{2}}\end{array}$ \\
\hline Strongly (SA) & $52(5)=260$ & 164.2 & 95.8 & 9177.6 & 58.9 \\
\hline Agree (A) & $65(4)=260$ & 164.2 & 95.8 & 9177.6 & 58.9 \\
\hline Agree & $21(3)=63$ & 164.2 & -101.2 & 10241.4 & -63.4 \\
\hline Indifferent (I) & $84(2)=168$ & 164.2 & -3.8 & 14.4 & 0.1 \\
\hline Strongly Disagree (SD) & $70(1)=70$ & 164.2 & -94.2 & 8873.6 & -54.0 \\
\hline Total & & & & & \\
\hline
\end{tabular}




\section{Significant at 0.05 levels}

Hypothesis five states that Non-consideration of beliefs and cultural factors of the environment has been identified as causes of the low patronage of new products. Finally, from the data in Table 5 of Appendix 1 , the analysis of results shows that the calculated chi-square value of 0.30 was found to be lower than the critical table value of 0.71 . The null hypothesis was therefore rejected.

The findings imply that there is no significant relationship between the low patronage of new products and the non-consideration of beliefs and cultural factors of the environment.

\section{ANALYSIS OF PERSONAL INTERVIEW}

Finally, the analysis of personal interview revealed that majority of the customers and bank staff agreed that with the increasing inflation in the economy, they avoid any new product that will add to the bank charges on their accounts. Majority agreed that the new products are not meeting their expectations for more services at low costs.

The common suggestions made by the respondents from personal interview are as follows:

i. Reduction of bank charges on new products. If possible, the introduction of new products initially should not attract charges as an encouragement, until they are used to the products.

ii. Holding of regular meetings of bank officers with their customers or organizing of seminars of enlightenment campaigns on the values new products offer.

iii. The sensitization and concrete security measures against internet fraud.

iv. On the ways of improving customer's attitude towards new products, apart from the need to considerably reduce high bank charges, majority agreed on reducing bureaucratic documentation in credit transaction, design new products that are suitable and realistic to the culture and environment of the consumers to meet local needs.

v. That bank should improve their adverts and publicity to focus more on utility cost and operation of new products (perceived) instead of advertising the size and profitability of the banks.

vi. vi. The recent cleansing policies of the Central Banks under the new Governor of Central Bank, Lamido Sanusi have not succeeded in improving the fortunes nor restored confidence in the commercial banking system as they are regarded as an exercise of "killing the goose that lays the golden eggs".

\section{IMPLICATIONS OF FINDINGS}

The main policy implication of the findings of this study to bank management is that for the patronage of new products especially electronic products, to he retained, they should research on creating value to customers in order to meet their expectations at low costs. With the recent economic down turn and the prevalent poverty in developing countries, customers are now more cost conscious inspite of their expectations.

In order to understand consumers' expectations or change to their negative attitude. the banks research departments or consultants should vigorous investigate their customers motivations and behaviour, as traditional research to longer produces the desired results in modern times.

Another policy implication is the Government through the Apex bank should endeavour to vigorously inspect and test the new products of banks in order to comply with the required standard for use by customers.

\section{CONCLUSIONS}

The study concludes that they were negative changes from the initial upsurge in the patronage of new products of banks to negative attitude of customers on patronage, in the post-consolidation era in Nigeria. This reduction in patronage of some new products is due to lack of perceived value by customers and prospective consumers due to their failed expectations. In addition, the excessive and multiple bank charges by banks, lack of awareness and excessive documentation and discrimination by banks on new mortgage and credit facilities have also greatly influenced the negative attitude of consumers.

It is therefore recommended that the management of banks should ensure that new products and services by banks add value at minimum cost to their consumers, especially in this period of global economic crisis. Banks should adhere strictly to apex banks regulations, especially with regards to bank charges and arm themselves properly to prevent fraudulent activities of internet fraudsters. However future reforms of Central Banks should avoid destroying the confidence of the commercial banking s', stem.

Finally, in the developing countries, especially African countries with entrenched culture and underdeveloped infrastructural facilities, there is need to adapt new technological products to their culture and local needs in future. This issue however requires further research.

\section{REFERENCES}

[1]. Agbonifoh, B.A. et al (1998), Marketing in Nigeria: Concepts, Principles and Decisions, Afritowers Book, P. 177.

[2]. Ibid,Pp. $187-188$

[3]. Business Day, by Anaro, A.; 1st September, 2008. 
[4]. Bamgboye, E.D. (1995), Marketing: Basic Concepts and Decisions, Delbe Publishers, Ikeja, Lagos, P. 64

[5]. Davidson, J. H. (1977), “Why Most New Consumer Brands Fail.' vlarAeting Journal (April, 1977), Pp. 55-59.

[6]. Dunne, Patrick, M. (1974), What Really are New Products? Journal of Business, December, Pp. 20-25. Also see: Agbonifoh et. al (1998), op. Cit, P. 322.

[7]. Etzel, M. J. et al (2007), Marketing, 14th Edition, McGraw-Full International, Ed. Fukikawa, (2008), Harvard Business Review, July to August, P. 36 .

[8]. Hopkins, D.S., Bailer E.L. (1971), New Production Pressures, Conference Board Record, June, Pp. 16-24.

[9]. Howard, J.A. and Sheith, J.N. (1967), The Theory of Buyer Behaviour (New York: John Willey), Pp. 27-28).

[10]. Ikpamcjo, P. and Obob, K. (2006), Essays in Banking Consolidation, Nigeria, (The ICEN Publications), P. 21.

[11]. Kotler, P. et a! (2004), Principles of Marketing, Person Education, Singapore, P. 298.

[12]. Nwokoye, G.N. (2004), Modern Marketing for Nigeria: Principles and Practice, African First Publishers Limited, Onitsha, Nigeria, P. 59

[13]. Porter, M.E. (1985), Competitive Advantage: Getting and Sustaining Superior

[14]. Performance, The Free Press, New York, in Smith, D.K. (2004). Marketing for Value Creation in Emerging Economies, Marketing ,Journal, Nigeria Institute of Marketing Pp. 12-14.

[15]. Smith, D.K. (2004), Op.Cit, P. 12-14

\section{APPENDIX \\ QUESTIONNAIRE \\ CONSUMER ATTITUDE TO NEW PRODUCTS IN BANKS IN NIGERIA IN THE POST-CONSOLIDATION ERA}

\section{INTRODUCTION}

Since the consolidation of banks in Nigeria in 2004, many banks have floated large stable of varieties of sophiscated new products and services, of which a good number of them have attracted low patronage by customers. This research is therefore aimed at empirically investigating the marketability, patronage and attitude of customers to the new products of banks and suggesting ways of improving customers' attitude to these new products.

Please note that this research is solely for academic purpose and all the persons and banks involved in giving us information will not be identified by name. In addition, all the information given to us will be treated with strict confidentiality.

Please, tick of the alternative answer that best corresponds with your opinion.

\section{SECTION A: PERSONAL DATA}

1. SEX
( ) (a) Male
( ) (b) Female

2. $\quad$ AGE
( ) (a) Under 20 years
( ) (b) 20-40 years
( ) (c) 41-60 years
( ) (d) above 60 years.

3. MARITAL STATUS

( ) (a) Married (Husband)

( ) (b) Married (Wife)

( ) (c) Single Parent

( ) (d) Not yet married.

4. PROFESSION
( ) (a) Banker
( ) (b) Company Worker
( ) (c) Civil Servant
( ) (d) Private Businessman Business Woman
( ) (e) Unemployed.

5. HIGFIEST EDUCATIONAL QUALIFICATION

( ) (a) School Certificate or Equivalent

( ) (b) First Degree/High National Diploma Professional Qualification

( )(c) Masters

( )(d) Doctor of Philosophy Degree 
( ) (e) None of the Above

\section{INCOME}

( ) (a) Below $\$ 12,000$ P.A (i.e below $\$ 1,000$ per month).

( ) (b) $\$ 2,001=\$ 120,000$ P.A. (i.e $\$ 1,000=\$ 10,000$ per month)

( ) (c) $\$ 120,001$ - $\$ 600,000$ P.A (i.e $\$ 10,000$ - $\$ 50,000$ per month)

( ) (d) $\$ 600,001$ - $\$ 2,400,000$ P.A (i.e $\$ 50,000$ - $\$ 200,000$ per month)

( ) (e) $\$ 2,400,000$ and above P.A ( $\$ 200,000$ per month and above).

\section{SECTION B: DATA ON ATTITUDE OF CONSUMERS TO NEW PRODUCTS}

7. The introduction of new products by banks has reduced the patronage of bank customers:
( ) (a) Strongly Agree
( ) (b) Agree
( ) (c) indifferent
( ) (d) Disagree
( ) (e) Strong Disagree

8. The Fraudulent activities of internet fraudsters and criminals have influenced the negative attitude of bank customers towards electronic products of banks.
( ) (a) Strongly Agree
( ) (b) Agree
( ) (c) Indifferent
( ) (d) Disagree
( ) (e) Strong Disagree

9. Excessive charges on use of electronic products and multiple bank charges have reduced the patronage of electronic products by bank customers:
( ) (a) Strongly Agree
( ) (b) Agree
( ) (c) Indifferent
( ) (d) Disagree
( ) (e) Strong Disagree

10. The poor perceived value of new products by bank customers has negatively affected the patronage of new products of banks.
( ) (a) Strongly Agree
( ) (b) Agree
( ) (c) indifferent
( ) (d) Disagree
( ) (e) Strong Disagree

11. The non-consideration of beliefs and cultural factors have been identified as causes of low patronage of new products:
( ) (a) Strongly Agree
( ) (b) Agree
( ) (c) Indifferent
( ) (d) Disagree
( ) (e) Strong Disagree

12. Are you aware of the benefits and applications of the newly introduced electronic products of your banks?
( ) (a) Very Large Extent
( ) (b) Large Extent
( ) (c) Indifferent
( ) (d) Little Extent
( ) (e) Very Little Extent

13. The main problem in securing credit facilities from the new credit/loan products in banks is the unwilling to grant loans to indual and small business enterprises: 
( ) (a) Strongly Agree

( ) (b) Agree

( ) (c) Indifferent

( ) (d) Disagree

( ) (e) Strong Disagree

14. The new products of banks, such as the new credit policies on margin loans, failed because of vested interest of management of banks:
( ) (a) Very Large Extent
( ) (b) Large Extent
( ) (c) Indifferent
( ) (d) Little Extent
( ) (e) Very Little Extent

15. The new cleansing policies of the new Governor of Central Bank in 2009 have improved the patronage of new products of banks:
( ) (a) Very Large Extent
( ) (b) Large Extent
( ) (c) Indifferent
( ) (d) Little Extent
( ) (e) Very Little Extent

16. The meddle someness or intervention of the new Governor of Central Bank on the policies and management of Central Bank has restored confidence on the operations of commercial banks in Nigeria.

( ) (a) Very Large Extent

( ) (b) Large Extent

( ) (c) Indifferent

( ) (d) Little Extent

( ) (e) Very Little Extent

17. Suggest ways to improve customers attitude to new banking products of your bank: 